\title{
Spring Migration and Subsistence Hunting of King and Common Eiders at Holman, Northwest Territories, 1996-98
}

\author{
TIM BYERS ${ }^{1}$ and D. LYNNE DICKSON ${ }^{2}$
}

(Received 30 March 2000; accepted in revised form 1 September 2000)

\begin{abstract}
A subsistence hunt for eiders by Inuvialuit of Holman, Northwest Territories, was observed over three spring harvest seasons from 1996 to 1998 to determine rates of crippling loss and to assess the sustainability of the harvest. King eiders (Somateria spectabilis) are the dominant waterfowl species harvested. The number of king eiders estimated to migrate past Holman in spring varied from $40696 \pm 4461$ (95\% confidence interval) in 1996 to $70018 \pm 14356$ in 1998, averaging 53000 per year. Common eiders (Somateria mollissima v-nigra) were much less abundant, varying from $2728 \pm 631$ to $6017 \pm 770$ birds, averaging 4400 annually. Peak numbers of king eiders moved through the study area in 1-8 days during the second to third week of June in all years, and common eiders peaked in 1-8 days during the first to second week of June. Strong winds may have hindered migration for a few days. Crippling loss rates during the hunt were low (3-9\%) in the first two years of the study, but increased to $13-20 \%$ in the early open-water spring of 1998, when hunters were forced to shoot over open water rather than shorefast ice. On the basis of these estimates and harvest data from the Inuvialuit Harvest Study, we determined that Holman hunters removed 3.7-6.9\% of the king eider subpopulation and less than $1 \%$ of the common eiders over the three-year study period. The present level of harvest of eiders available to Holman hunters is likely sustainable. However, more information on natural mortality and recruitment rates, particularly for king eiders, is needed to confirm this.
\end{abstract}

Key words: king eider, Somateria spectabilis, common eider, Somateria mollissima v-nigra, harvest, crippling loss, migration

RÉSUMÉ. La chasse de subsistance à l'eider menée par les Inuvialuit de Holman (Territoires du Nord-Ouest) a fait l'objet d'une étude sur les trois saisons de récoltes printanières allant de 1996 à 1998, afin de déterminer les taux de pertes dues aux blessures et d'évaluer la viabilité de la récolte. L'eider à tête grise (Somateria spectabilis) représente la plus importante espèce de sauvagine récoltée. L'estimation du nombre d'eiders à tête grise passant près d'Holman durant la migration printanière variait de $40696 \pm$ 4461 (intervalle de confiance de 95 p. cent) en 1996 à $70018 \pm 14356$ en 1998, soit une moyenne annuelle de 53000. L'eider à duvet (Somateria mollissima v-nigra) était beaucoup moins abondant, variant de $2728 \pm 631$ à $6017 \pm 770$ individus, soit une moyenne annuelle de 4400. Le nombre d'eiders à tête grise passant dans la zone d'étude atteignait chaque année son apogée durant 1 à 8 jours pendant la deuxième et la troisième semaine de juin, et celui des eiders à duvet durant 1 à 8 jours pendant la première quinzaine de juin. Il se peut que des vents forts aient entravé la migration pendant quelques jours. Le taux de pertes dues aux blessures survenues au cours de la chasse était faible (de 3 à 9 p. cent) durant les deux premières années de l'étude, mais a augmenté jusqu'à 13 à 20 p. cent au début de la période d'eau libre printanière de 1998, quand les chasseurs devaient tirer au-dessus de l'eau libre plutôt qu'au-dessus de la glace de rive. En s'appuyant sur ces estimations et sur les données de prélèvements renfermées dans l'étude sur la récolte des Inuvialuit, on a établi que les chasseurs d'Holman avaient prélevé de 3,7 à 6,9 p. cent de la sous-population de l'eider à tête grise et moins de 1 p. cent de l'eider à duvet au cours des trois années constituant la période d'étude. Il semble que le niveau de récolte actuel de l'eider s'offrant aux chasseurs d'Holman soit viable, mais pour le confirmer, on a besoin d'un supplément d'information sur la mortalité naturelle et les taux de recrutement, en particulier dans le cas de l'eider à tête grise.

Mots clés: eider à tête grise, Somateria spectabilis, eider à duvet, Somateria mollissima v-nigra, récolte, pertes dues aux blessures, migration

Traduit pour la revue Arctic par Nésida Loyer.

\section{INTRODUCTION}

Unlike most other waterfowl that breed in North America, eiders in western Arctic Canada do not follow a predominantly north-south migration across the continent. Rather, they migrate offshore from wintering areas in the North Pacific and Bering Sea past Point Barrow, Alaska, then eastward across the Beaufort Sea to nest in northern Alaska and the Canadian western and central Arctic (Palmer, 1976).

Both king eider and common eider populations of northwestern North America have declined over the past 20 to 30 years (Dickson et al., 1997; Suydam et al., 1997, 2000a). Recent population estimates of 370000 king eiders and 73000 common eiders represent a decline of

\footnotetext{
${ }^{1}$ Byers Environmental Studies, \#2 - 740 Dorchester Ave., Winnipeg, Manitoba R3M 0R6, Canada; byerses@ escape.ca

${ }^{2}$ Canadian Wildlife Service, Environment Canada, Room 200, 4999 - 98 Ave., Edmonton, Alberta T6B 2X3, Canada

(C) The Arctic Institute of North America
} 
more than 50\% over 20 years for both species (Suydam et al., 2000a). Fabijan et al. (1997) examined hunting as a potential cause of this decline. Those authors determined that $2-5 \%$ of these populations is harvested annually in Alaska and Canada, and over $95 \%$ of that harvest is king eider. They did not find evidence of overharvesting. However, they recommended that the eider hunt at Holman, Northwest Territories, be examined more closely, since Holman accounts for about $20 \%$ of the overall harvest, yet might be drawing from relatively small subpopulations as the eiders approach their nesting grounds. Hence, this study was initiated jointly by the Inuvialuit and the Canadian Wildlife Service to determine the total numbers of eiders migrating past Holman annually, describe the eider hunt, quantify crippling losses, and assess the effect of the harvest on eider numbers near Holman.

Most of the eiders harvested in western Arctic North America are taken by subsistence hunters; only about $2 \%$ are taken by sport hunters (Fabijan et al., 1997). Within the Inuvialuit Settlement Region (ISR) in western Arctic Canada, the Inuit community of Holman accounts for $99 \%$ of the total eider harvest of 2000-5000 birds (Fig. 1). Eider hunting is an important subsistence activity of Holman people. Condon et al. (1995) found that duck hunting had the highest level of participation of all subsistence hunting and fishing activities of Holman residents. The same authors also found that $14 \%$ of all evening meals over a full year contained eiders, even though the hunt occurs over only about $8 \%$ of the year. For over 40 years, the preferred location for the Holman eider harvest has been at a hunting camp called Masoyuk. This camp is situated approximately $6 \mathrm{~km}$ south of Holman at a narrow channel between Victoria Island and Holman Island (Fig. 1). The harvest occurs during spring migration and consists primarily of king eiders (Somateria spectabilis), though smaller numbers of Pacific common eider (Somateria mollissima v-nigra) are also taken.

\section{STUDY AREA}

Eider migration and harvest were observed at Holman Island $\left(70^{\circ} 39^{\prime} \mathrm{N}, 117^{\circ} 43^{\prime} \mathrm{W}\right)$, an island $4 \mathrm{~km}$ long located less than $100 \mathrm{~m}$ off the west-central coast of Victoria Island, Northwest Territories (Fig. 1). In most spring seasons, a system of annually recurring leads (linear areas of open water within sea ice) stretches from near the Alaska/Yukon border eastward to Cape Bathurst, paralleling the coast, and extends northward along the western coastline of Banks Island. The Cape Bathurst polynya (an annually recurring, nonlinear area of open water surrounded by sea ice), shaped by wind and the moving pack ice of the Beaufort Sea, starts to form at the western entrance of Amundsen Gulf in April (Smith and Rigby, 1981). Eiders that migrate past Holman in late May and June on their journey to their nesting grounds come from staging areas in the leads off Cape Bathurst and the west coast of Banks Island (Fig. 2; Barry, 1986; Alexander et al., 1997). Leads develop around the northern and eastern perimeter of Amundsen Gulf, showing considerable annual variation in timing and length. In most years, by late May or early June nearshore leads run along the west coast of Victoria Island, extending from Minto Inlet through our study area and across the entrance to Prince Albert Sound. Breakup of Amundsen Gulf usually commences in late June or early July, but it can begin as early as mid-May, as in 1998. Freeze-up of the gulf begins in sheltered coves and bays by late September. The gulf is normally choked with ice from late October through June (Anonymous, 1968).

Holman is a community of over 450 people, about $95 \%$ of whom are Inuvialuit-Inuit of the western Canadian Arctic (see Fig. 1). Most Inuvialuit residents of Holman are descendants of the Copper Inuit from Minto Inlet (the "Kanghiryuatjagmiut"), Prince Albert Sound (the "Kanghiryuarmiut"), and Read Island on Dolphin and Union Strait (the "Puivlingmiut") (Condon, 1987). A small number of Mackenzie Delta Inuvialuit moved into the area in the 1930s and 1940s. Over the course of three decades, families from these Inuit groups gradually moved into the settlement of Holman. The last nomadic family moved into a permanent home in the settlement in 1967 (Condon, 1987).

\section{METHODS}

To estimate the size of the eider stocks from which the community of Holman harvests, counts of migrating eiders were made from late May to 25 June in 1996, 1997, and 1998 simultaneously from two sites on opposite sides of Holman Island (Fig. 1). One site was located $60 \mathrm{~m}$ above sea level on the west side of the island, looking seaward. The other was on the east side, in the narrow passage between Holman Island and Victoria Island. Two sites were necessary because eider migration occurred on both sides of the island, and no single vantage point could give us close proximity to both flyways. Each day during the period of spring migration, counts were conducted for two-hour periods every four hours, giving six counts totalling 12 hours per day. The counts from both sites were combined for each count period. We assumed that eiders migrating past Holman Island were all birds that winter west of the continent. Thus, the number of birds moving northwest in the direction opposite to the migration path (this averaged from $2.2-12.9 \%$ of the daily counts for king eiders, $23.6-27.4 \%$ daily for common eiders) was subtracted from the total number moving southeast to avoid counting twice any birds that had doubled back along the route. We also assumed that flocks in mid to late June that were composed of more than $80 \%$ males and travelled in a direction reverse to that of the main spring migratory movement were moult-migrants, post-breeding males heading westward to moulting areas. We did not include them in the counts. The mean of the six daily counts, multiplied 

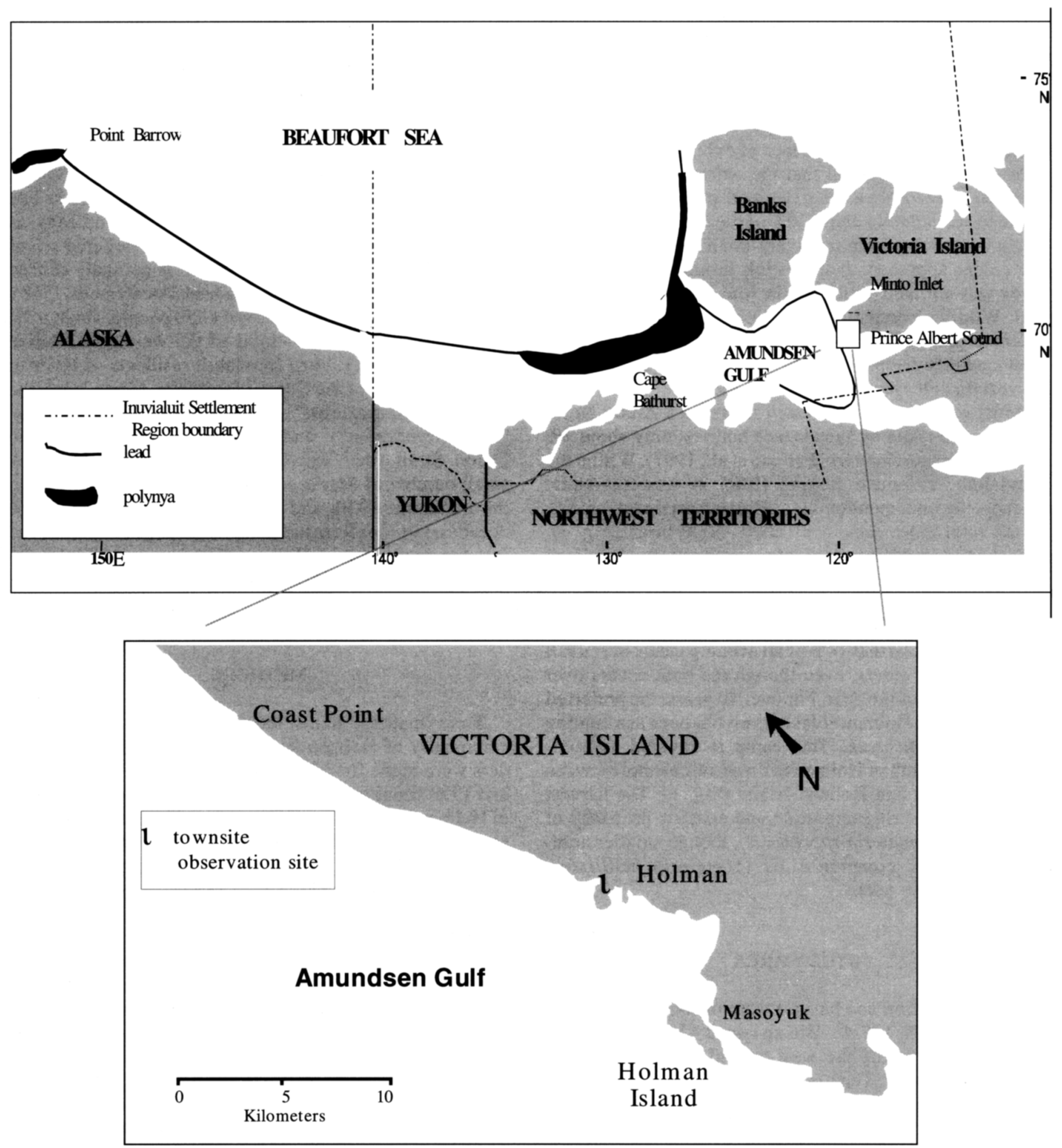

FIG. 1. General locations of open-water leads and the polynya system in the western Arctic in spring, after Smith and Rigby (1981) and Alexander et al. (1997), with expanded view of the study area.

by 12 , gave the estimated number of eiders migrating past Holman Island each day. The sum of the daily estimates provided a point estimate of the number of king and common eiders migrating past Holman each spring. Variances and confidence intervals of the population estimates $(\hat{Y})$ were calculated for each species.
The sample variance of each daily count mean (of the six counts) was calculated using the formula: $\lambda_{j}=\left(s_{j}^{2} / n_{j}\right)$ $\left(1-n_{j} / N_{j}\right)$, where $s^{2}$ is the variance of the day's watch counts for day $\mathrm{j}, \mathrm{n}$ is number of watches per day $(\leq 6)$, and $\mathrm{N}$ is the total number of potential watch periods (12) in a day. 

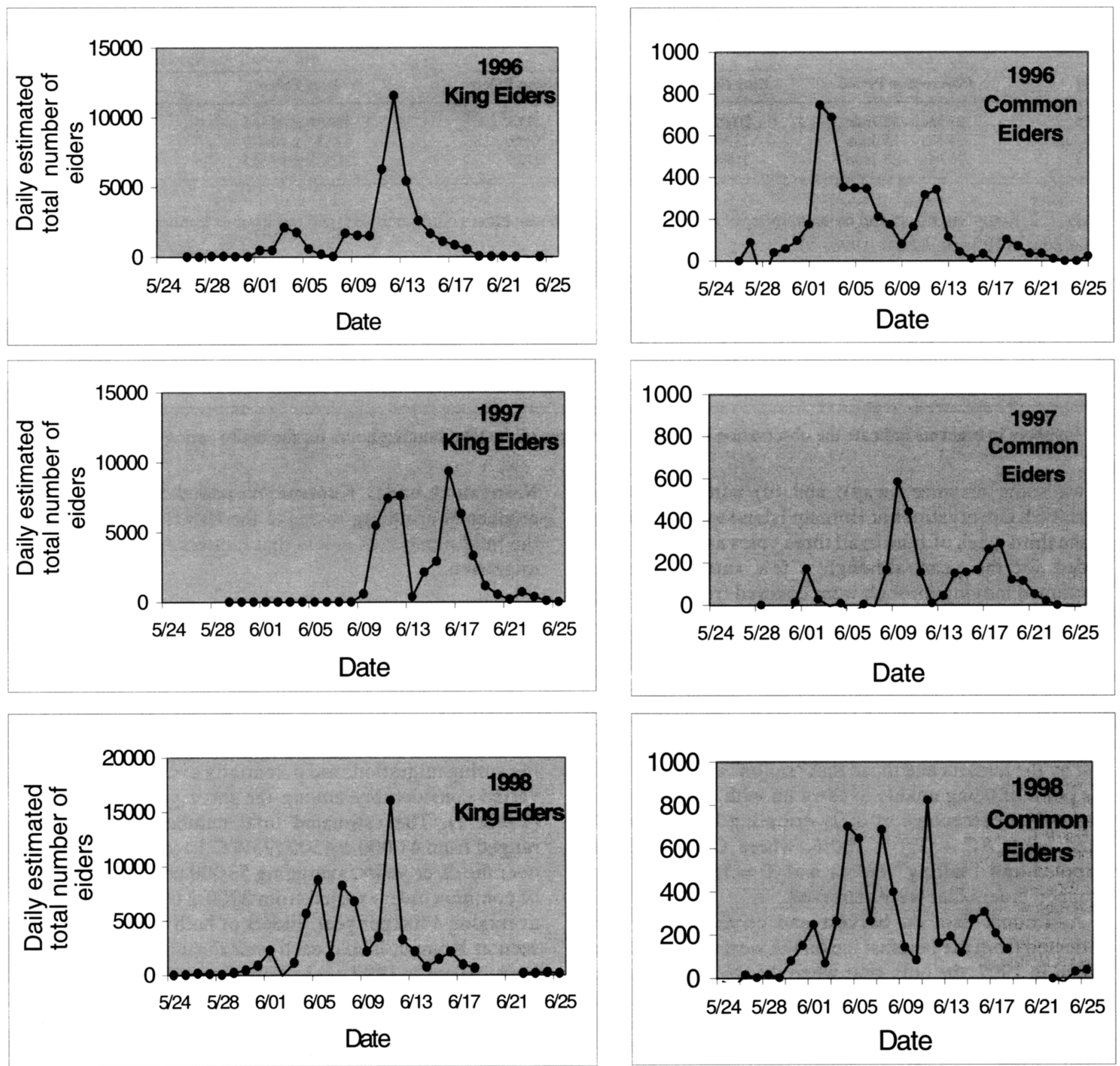

FIG. 2. Daily numbers of eiders migrating past Holman Island in spring, 1996-98.

Each daily variance $\left(\lambda_{\mathrm{j}}\right)$ was multiplied by $\mathrm{N}_{\mathrm{j}}{ }^{2}$ to derive the variance of the daily estimated eider totals: $V_{j}=\left(\lambda_{j}\right)$ $\mathrm{N}_{\mathrm{j}}{ }^{2}$. All daily $\mathrm{V}_{\mathrm{j}}$ for the entire sampling period were summed to estimate the population variance (Rugh and Braham, 1979; Braham, 1982). The 95\% confidence interval was determined using the formula:

$$
\hat{\mathrm{Y}} \pm \mathrm{t}_{\mathrm{j}-1} \times\left(\sum \mathrm{V}_{\mathrm{j}}\right)^{0.5}
$$

where $t_{j-1}$ is taken from the $t$-distribution for $\mathrm{j}$ sample.

Each year, we observed about $20 \%$ of the total hunt period at Holman Island (Table 2). Observations ran up to
11 hours per day, averaging between 4.5 and 6 hours, most often from noon to midnight, when hunting activity was greatest. Observations ran simultaneously with migration watch periods, as well as between them. Hunt-monitoring sites at Masoyuk provided clear, unobstructed views of all hunting activity along the east side of Holman Island. All hunting activity and flying and killed/crippled ducks were easily observed at these sites. Data collected for catch rate and crippling loss calculations were (a) number of active hunters; (b) time of day when hunters encountered each flock; (c) number of eiders dropped and number struck by pellets, but "sailing" (i.e., setting their wings and gliding 
TABLE 1. Number of eiders migrating past Holman Island in spring, 1996-98.

\begin{tabular}{|c|c|c|c|c|c|}
\hline \multirow[b]{2}{*}{ Year } & \multirow[b]{2}{*}{ Observation Period } & \multicolumn{2}{|c|}{ Net Number Seen } & \multicolumn{2}{|c|}{ Estimated Total Number $\pm 95 \%$ C.I. } \\
\hline & & King Eiders & Common Eiders & King Eiders & Common Eiders \\
\hline 1996 & 27 May-25 June & 20318 & 2274 & $40696 \pm 4461$ & $4619 \pm 326$ \\
\hline 1997 & 29 May-25 June & 23702 & 1388 & $48555 \pm 10570$ & $2728 \pm 631$ \\
\hline 1998 & 23 May-25 June & 31966 & 2725 & $70018 \pm 14355$ & $6017 \pm 770$ \\
\hline
\end{tabular}

TABLE 2. Sampling effort and mean number of eiders (king and common eiders combined) bagged per hour of hunting during the spring eider hunt at Holman Island, 1996-98.

\begin{tabular}{|c|c|c|c|c|c|}
\hline Year & $\begin{array}{c}\text { Number of } \\
\text { Observation Days }\end{array}$ & $\begin{array}{c}\text { Total Observation } \\
\text { Hours }^{1}\end{array}$ & $\begin{array}{l}\text { Number of Hunters } \\
\text { that Harvested Eiders }\end{array}$ & $\begin{array}{c}\text { Total Man-Hours } \\
\text { of Hunting Observed }\end{array}$ & $\begin{array}{l}\text { Eiders Bagged } \\
\text { per Man-Hour }\end{array}$ \\
\hline 1996 & 10 & $54.5(21.0 \%)$ & 47 & 371.5 & 0.9 \\
\hline 1997 & 9 & $54.0(22.5 \%)$ & 44 & 367.8 & 0.9 \\
\hline 1998 & 13 & $60.8(19.5 \%)$ & 26 & 168.0 & 1.6 \\
\hline
\end{tabular}

${ }^{1}$ Numbers in brackets indicate the observation hours as percentages of the total hunting hours for the entire spring hunt.

down some distance away); and (d) number of eiders retrieved. Observations at Holman Island were terminated in the third week of June in all three years as the eider hunt ended for the year, although a few small flocks that continued moving through were counted from hills on the western edge of town until June 25.

The catch per unit of hunting effort was calculated as the mean number of eiders retrieved per hunter per hunting-hour. Struck but unretrieved eiders (called "crippling loss" here, but also referred to in the literature as "struck but lost" and "unretrieved kill") were those dropped and lost by the hunters and those that "sailed" away, injured to the point of being unable to carry on with their migratory flight. The percentage of daily crippling loss was calculated as: $[\mathrm{C} /(\mathrm{C}+\mathrm{T})] \times 100 \%$, where $\mathrm{C}=$ number of crippled and "sailing" eiders and $\mathrm{T}=$ total number of dropped eiders that were retrieved.

Additional data on harvest and crippling loss were collected from the landfast ice on the west side of Holman Island in 1997, the only year when the ice at that location was stable enough to offer a secure hunting platform. Data from boat-based hunting in open water near shore were obtained in 1998. Each year, we inspected bags (24 in 1996, 50 in 1997, and 30 in 1998), from a maximum of 17 hunters, to determine bag sizes and eider sex ratios.

Although Holman Island is the location preferred by most eider hunters for its close proximity to town and abundance of eiders, some hunting also occurs along the coast northwest of town. Thus, the harvest data we collected at Holman Island do not represent the total harvest for the community of Holman and would be unsuitable for assessing the potential impact of the Holman harvest on eider populations. Consequently, for this analysis, we used the spring harvest numbers obtained by the Inuvialuit Harvest Study (IHS). This is a recall survey that involves all hunters in all hunting areas around Holman. Published IHS data were obtained from Fabijan et al. (1997), and unpublished data were provided by M. Fabijan, S.
Nasogaluak, and D. Kuptana. We added the total estimated number of crippling losses to the IHS figures to estimate the total number of eiders that hunters removed from the migration.

\section{RESULTS}

\section{Eider Migration}

The number of eiders moving past Holman Island during spring migration, and potentially available for harvest, varied considerably among the three years of the study (Table 1). The estimated total number of king eiders ranged from $41000 \pm 4500$ (95\% C.I.) to $70000 \pm 14000$ over the three years, averaging 53000 per year, while that of common eiders varied from $2700 \pm 600$ to $6000 \pm 800$, averaging 4400 per year. Eiders of both species were first seen at Holman Island each year during the last week of May, except in 1997, when king eiders did not arrive until 7 June. The peak passage of common eiders occurred in early June in all years (2-11 June), whereas the peak passage of king eiders occurred about a week later, on 10-17 June (Fig. 2).

Twice during peak migration of king eiders, their movement was substantially reduced while strong headwinds blew from the south and southeast. Daily maximum southeast winds of greater than $50 \mathrm{~km} / \mathrm{h}$ (with daily means of $24-49 \mathrm{~km} / \mathrm{h}$ ) were recorded on 13-14 June 1997 and 910 June 1998 (Fig. 3). Maximum headwind speeds were below $40 \mathrm{~km} / \mathrm{h}$ during observation periods in 1996, the only year that had an uninterrupted peak migration (Fig. 2).

Wind effects on common eider migration were not apparent, although few common eiders moved through the study area on the windy days that interrupted the king eider migration. The largest two-hour count of common eiders in 1996 (309) occurred when there was a headwind of $37 \mathrm{~km} / \mathrm{h}$. 

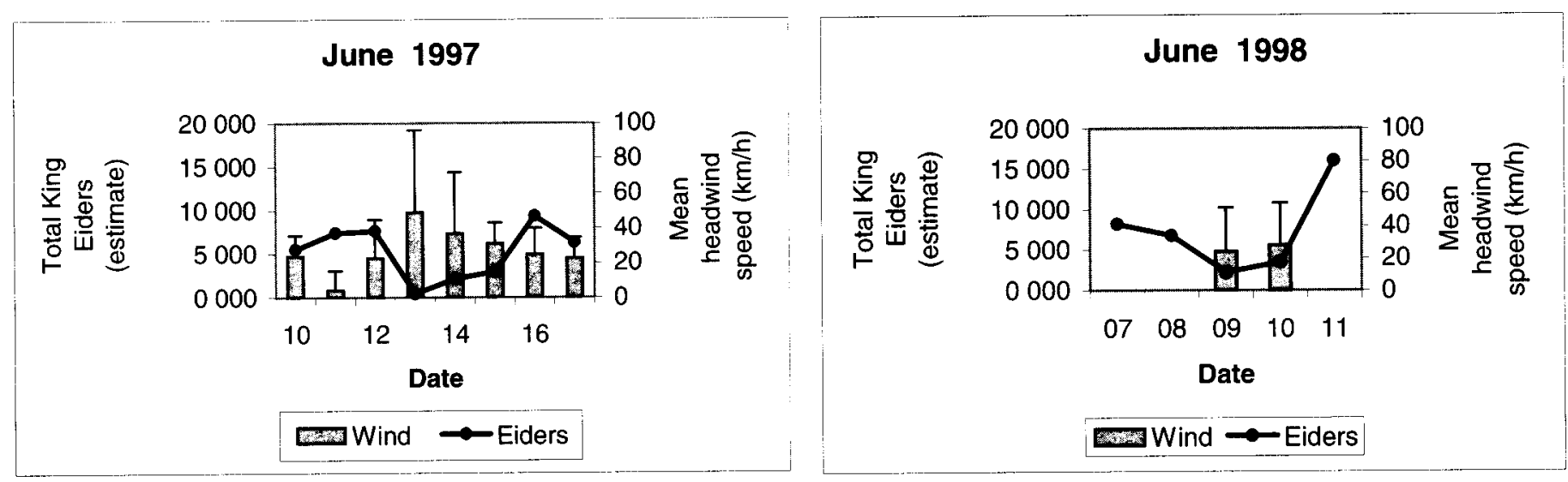

FIG. 3. Effect of headwind speed on number of king eiders passing Holman Island during peak spring migration in 1997 and 1998 . Shaded bars show mean headwind speed, while top of black line shows highest headwind speed reached each day. (No headwinds occurred on 7, 8, or 11 June in 1998.)

Fog did not appear to interfere with the eider migration. In both 1997 and 1998, the largest king eider flocks (more than 100 birds) and the highest two-hour counts (2819 king eiders on 11 June 1997; 3869 king eiders and 110 common eiders on 11 June 1998) occurred in fog, with visibility of less than $1 \mathrm{~km}$.

The intensity of eider migration did not vary with the time of day. Combining the three years of data, and removing count periods when headwinds exceeded $50 \mathrm{~km} / \mathrm{h}$, results in an even distribution of mean king and common eider numbers among all two-hour observation periods throughout the day (Rayleigh test: $\mathrm{z}=0.075$, $p>0.5$ for king eiders; $\mathrm{z}=0.199, p>0.5$ for common eiders).

Male eider migrants were almost exclusively mature ducks. In three spring seasons at Holman, we saw no immature male common eiders and only two immature male king eiders. Age-class determination was less distinct for the females, so it was not noted.

In mid-June of 1996, the fast-ice edge was less than $1 \mathrm{~km}$ from Holman Island (Fig. 4). In the same time period in 1997, the ice edge was over $15 \mathrm{~km}$ away from Holman Island. However, a continuous lead of open water running from Coast Point to the mouth of Prince Albert Sound formed near shore at about the same distance from Holman Island as the edge of the fast ice in 1996. In both years, eiders migrating near shore through the study area were concentrated along this lead or ice edge. In 1998, in contrast to the two previous years, early and rapid breakup and disappearance of sea ice occurred in late May, about one month earlier than normal. As a result, no fast ice was present through June anywhere between Coast Point and Holman Island.

\section{Harvest Rate}

Fewer hunters participated in the eider hunt in 1998 than in the previous two years (Tables 2 and 3 ). Because of the unusually early open water, boats instead of snowmobiles had to be used during most of the harvest.
Since fewer people owned a boat, this prevented many from hunting. Those that did hunt at Holman Island in 1998 encountered nearly twice as many flocks per hour as in the previous two years $(7.5$ flocks/h in 1998 , versus 4.3 in 1996 and 4.6 in 1997). The greater abundance of eiders resulted in nearly double the rate of harvest. The annual mean catch of eiders in the three years of this study increased from 0.9 eiders/man-hour of hunting in the first two years to 1.6 in 1998 (Table 2), with a maximum of 3.6 on any given day. Conversely, there was very little hunting success from camps northwest of town in 1998, as the fast ice normally used as a platform for shooting the eiders had melted. Eiders migrating between Coast Point and Holman tended to fly more than $50 \mathrm{~m}$ offshore, beyond shotgun range of hunters along shore. Thus, hunters who did not hunt from boats in 1998 had little success (D. Notaina, G. Okheena, pers. comm. 1998).

\section{Crippling Loss}

The overall crippling loss rate at Holman Island was $3.2 \%(\mathrm{n}=371$ struck eiders $)$ in 1996 and $3.6 \%(\mathrm{n}=278)$ in 1997 (Table 3). In both years, hunting occurred primarily at Masoyuk on the east side of the island. The $70 \mathrm{~m} \mathrm{high}$, $4 \mathrm{~km}$ long barrier of Holman Island kept eiders dropped on the east side of the island confined to the ice of the inside passage, where they were easily accessible and highly visible. Reasons for not retrieving ducks were either that wounded ducks set their wings and "sailed" out of the immediate hunt area, or that they dropped into ice cracks or onto land. Retrieval on land was a problem only with female eiders, whose brown plumage is camouflaged from sight by the surrounding rock. Eider behaviour in response to hunting might also have contributed to crippling losses at Masoyuk. When encountering hunt parties, eiders quickly rose, gaining altitude as rapidly as possible without altering flight direction. Consequently, hunters positioned behind the "front lines" of hunters would often be forced to shoot at eiders at higher altitudes, which increased the possibility of wounding them. But this was offset by 

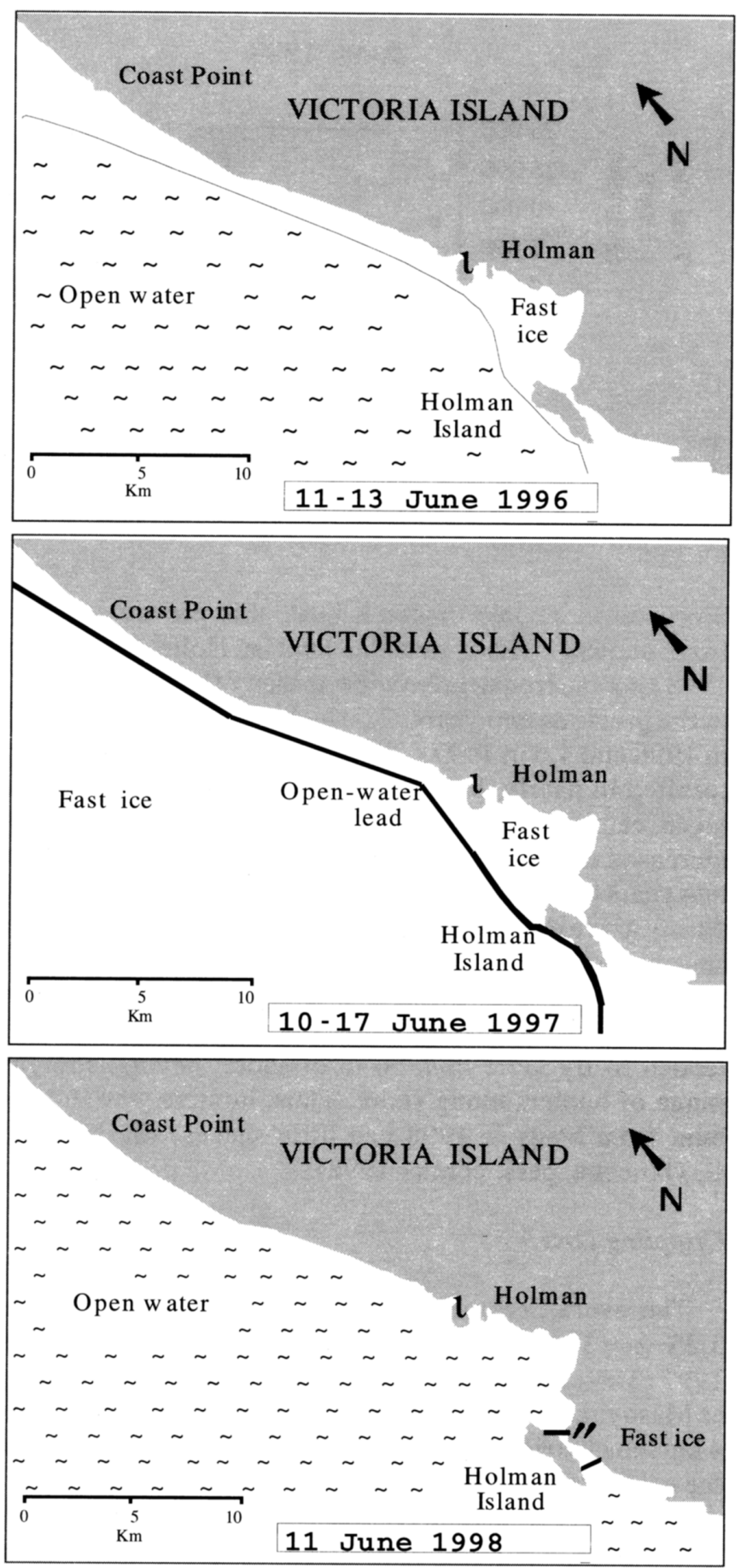

FIG. 4. Sea-ice conditions during peak migration in eider-hunting area of Holman, Northwest Territories, 1996-98.

hunters most often picking as preferred targets crippled birds that "sailed" lower toward them from the front lines.

A crippling loss rate of $9.1 \%(n=44$ struck eiders $)$ was obtained for the seaward (west) side of Holman Island in 1997. The higher loss, compared to the east side, was due to the proximity of open water west of the island. Some dead or wounded eiders "sailed" into the water or behind small pressure ridges on the ice that hid their locations. We did not obtain crippling loss rates at camps northwest of
Holman in 1996 and 1997. However, we believe they would have approximated the $9 \%$ rate observed on the fast ice west of Holman Island in 1997, since ice conditions were similar at both hunting sites.

Crippling losses increased substantially in the ice-free spring of 1998 compared to the two previous years. Seventeen boat hunters in 1998 had a combined crippling loss rate of $20 \%$ ( $n=56$ struck eiders), while two hunters on the shore northwest of Holman also lost two of the ten they dropped. The higher crippling loss rate was largely due to the absence of fast ice, a stable platform preferred by hunters for more accurate shooting (D. Kuptana, G. Okheena, pers. comm. 1998). It was also more difficult to retrieve wounded ducks in water than on ice, because they tended to dive and swim away unseen from the boat or dive beneath the remaining ice on the east side of Holman Island.

\section{Species and Sex Composition of Harvested Eiders and Variability of Hunting Effort}

A comparison of the species composition of all eiders migrating past Holman Island versus those that were harvested suggested some species selection by hunters (Table 4 ). Even though common eiders made up $8.5 \%$ (range $=5.1$ $10.8, \mathrm{n}=3$ years) of the migrating eiders during the hunt period, this species made up only $1.4 \%$ (range $=0.9-2.3$ ) of the eider harvest as estimated by the IHS at Masoyuk. On-site bag checks were not as conclusive in this regard. This apparent selection for king eiders was likely not an artifact of shooting error. Mixed flocks of king and common eiders were uncommon (2.7\% of all flocks in 1997 to $5.5 \%$ in 1998), and females unaccompanied by males were almost nonexistent. Thus, the probability of hunters accidentally hitting an undesired species or mistakenly identifying common eiders as king eiders is considered to be low. The senior author, who spent time with two hunters, noted that they would prepare to aim at oncoming flocks of common eiders but would not shoot once they had identified the species. These and other hunters said that they preferred the taste of king eiders.

Bag checks at Masoyuk showed no selection for sex while hunting king eiders, as each year the sex ratio of bagged ducks was not significantly different from the mean of all king eiders flying past the island during the hunt (Table 5). However, experienced hunters often aimed for the females in a flock (D. Kuptana, pers. comm. 1996), which may explain why the IHS found that the proportion of males in the bagged birds was significantly smaller than that of males in the migration in 1997 and 1998 (t-test: $p<0.001)$. Hunters knew, and we observed, that an accompanying male often circled about or landed in the vicinity of a downed female, giving hunters the opportunity to bag a pair for every female dropped. There might have been some selection for females when shooting at common eiders (Table 5), although the sample size of this harvested species was too small to be certain. Interannual variability of sex ratios of harvested eiders was higher for 
TABLE 3. Estimated number of eiders bagged, crippling loss, total hunting mortality, and the proportion of the spring eider migration harvested by all Holman residents, 1996-98.

\begin{tabular}{|c|c|c|c|c|c|c|c|}
\hline Species & Year & $\begin{array}{c}\text { Total Number } \\
\text { of Eider Hunters }{ }^{1}\end{array}$ & $\begin{array}{c}\text { Total harvest }{ }^{1} \\
\text { (\% at Holman Island) }\end{array}$ & $\begin{array}{l}\text { Crippling } \\
\operatorname{loss}^{2}(\%)\end{array}$ & $\begin{array}{l}\text { Total Hunting } \\
\text { Mortality }\end{array}$ & $\begin{array}{c}\text { Total Migrating } \\
\text { Eiders }\end{array}$ & $\begin{array}{c}\text { Hunt Mortality } \\
\text { (\% of eider migration) }\end{array}$ \\
\hline \multirow[t]{3}{*}{ King Eider } & 1996 & 64 & $2680(82)$ & $3.2-9.1^{3}$ & 2801 & 40696 & 6.9 \\
\hline & 1997 & 65 & $2390(71)$ & $3.6-9.1^{3}$ & 2517 & 48555 & 5.2 \\
\hline & 1998 & 45 & 2077 ( 78$)$ & $13.0-20.0^{4}$ & 2597 & 70018 & 3.7 \\
\hline \multirow{3}{*}{ Common Eider } & 1996 & 64 & $28(100)$ & $3.2-9.1$ & 29 & 4619 & 0.6 \\
\hline & 1997 & 65 & $24(100)$ & $3.6-9.1$ & 26 & 2728 & 0.9 \\
\hline & 1998 & 45 & $15(73)$ & $13.0-20.0$ & 19 & 6017 & 0.3 \\
\hline
\end{tabular}

${ }^{1}$ From Inuvialuit Harvest Study data (Fabijan et al., 1997; S. Nasogaluak, pers. comm. 1998).

${ }^{2}$ Since very few common eiders were dropped, hunt-monitoring data for the two species were combined. Crippling loss was assumed to be the same for both eider species.

${ }^{3}$ The $3.2 \%$ and $3.6 \%$ crippling losses apply to the Holman Island harvest (from Masoyuk and the west side of the island), and the 9.1\% to the harvest northwest of town.

${ }^{4}$ Since an unknown but large portion of the hunt took place from boats, only the $20 \%$ figure was used in the calculation of total mortality, generating a conservative estimate.

common eiders than for king eiders, likely because of the small sample sizes of common eiders.

We observed people hunting for up to 16 straight hours, but daily hunting effort was variable for each hunter and among hunters. There were more hunters active on weekends than during the workweek. In 1996, a mean 6.2 hunters/hr were active ( $\mathrm{n}=25$ hours) during the workweek versus $10.1(\mathrm{n}=14)$ on weekends; in 1997, it was $6.5(\mathrm{n}=$ 46) versus $8.3(\mathrm{n}=8)$; in 1998 , it was $2.5(\mathrm{n}=32)$ versus $4.0(n=24)$. These observations all took place between noon and 0100 , the period when hunters are most active; hours with no hunting activity were not included.

Six hunters over the course of the study volunteered information on the number of eiders they harvested each year. These ranged from 37 to 200 per hunter, and more than $98 \%$ of the harvest was king eiders. One household of three hunters (a married couple and their teenaged son) bagged 375 eiders in 1998. Even taking into account that these hunters were providing meat for an extended family, Holman hunters considered this an exceptionally large harvest for a single household in any one year (D. Kuptana, G. Okheena, M. Nigiyok, D. Notaina, pers. comm. 1998).

\section{DISCUSSION}

\section{Eider Migration}

In 1998, the number of king and common eiders migrating past Holman Island increased substantially. It is unknown whether this increase from the preceding two years was due to the eiders' taking a different migration route (perhaps related to annual differences in location of open water) or to a large influx of first-year breeders. Alexander et al. (1997) found large annual variation in the relative use of the two key spring staging areas for king eiders in the Beaufort Sea. This suggests that king eiders do sometimes alter their spring migration route, perhaps in response to ice conditions or weather patterns. On the other hand, evidence suggests there may have been growth in the breeding population in 1998. Suydam et al. (2000b) observed a substantial increase in the number of king eiders passing Point Barrow, Alaska, from spring migration to fall migration in 1996 (from 371000 to 508 000). They attributed this increase to a highly productive year on the nesting grounds. Since king eiders do not breed until two years of age, the part of the breeding population that migrates past Holman would not show a corresponding increase until 1998. Thus, the increase we observed could have been due to true population growth.

Observations of peak eider movements at both Point Barrow and Holman Island in 1996 suggest that king eiders remained in the eastern Beaufort Sea staging areas for about a month before continuing on their journey to the nesting grounds. About $80 \%$ of the king eiders passing Point Barrow had entered the Beaufort Sea by 15 May (Suydam et al., 2000b), whereas peak numbers were not seen at Holman until 13 June. It is unknown how much energy king eiders acquire from the Beaufort Sea in preparation for the breeding season. However, we do know that food resources in the Beaufort Sea are essential to their survival during spring migration. In years when leads in the eastern Beaufort Sea are not present for extended periods, thousands of migrating king eiders may die of starvation (Barry, 1968; Fournier and Hines, 1994).

Common eiders arrived in the Holman area several days earlier in spring than king eiders, a pattern consistent with Holman traditional knowledge (Kay et al., 1996). This is unlike the earlier part of the eider migration, when king eiders are seen before common eiders at Point Barrow (Woodby and Divoky, 1982; Suydam et al., 1997).

Most king and common eiders passing Holman Island were paired, concurring with what Suydam et al. (1997, $2000 \mathrm{a}, \mathrm{b})$ saw at Point Barrow. The proportion of males we observed (55\% for king eiders and 54\% for common eiders) was also similar to what Suydam et al. (2000b) 
TABLE 4. Comparison of species composition of eiders harvested versus migrating past Holman Island during the spring harvest period, 1996-98.

\begin{tabular}{|c|c|c|c|c|c|c|c|}
\hline \multirow[b]{3}{*}{ Migration } & \multicolumn{7}{|c|}{ Percent Common Eiders (Sample Size) } \\
\hline & \multicolumn{2}{|c|}{$\begin{array}{c}1996 \\
28 \text { May-16 June }\end{array}$} & \multicolumn{2}{|c|}{$\begin{array}{c}1997 \\
9-19 \text { June }\end{array}$} & \multicolumn{2}{|c|}{$\begin{array}{c}1998 \\
28 \text { May-17 June }\end{array}$} & 3-Year Total \\
\hline & 10.8 & (21937) & 5.1 & (24057) & & (29200) & 8.5 \\
\hline Harvest ( bag checks) & 9.1 & (296) & 6.2 & (370) & 7.0 & $(285)$ & 7.4 \\
\hline Harvest (from IHS) & 1.0 & (1993) & 2.3 & (1634) & 0.9 & $(1632)$ & 1.4 \\
\hline
\end{tabular}

TABLE 5. Comparison of sex composition of eiders harvested versus migrating past Holman Island during the spring harvest period, $1996-98$

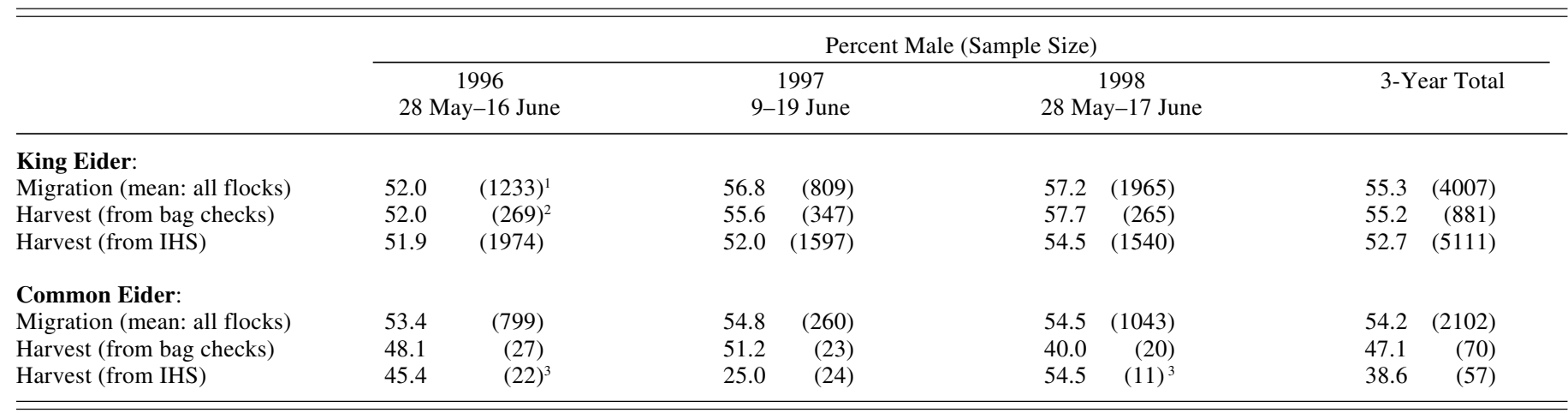

${ }^{1}$ Number of eider flocks.

2 Total number of harvested eiders seen in all bags inspected.

${ }^{3}$ The IHS number is smaller than the bag check number because some eiders were reported to the IHS as "sex unknown."

noted at Point Barrow (56\% king eiders and 57\% common eiders) in 1996. In 1994, Suydam et al. (1997) found that males made up 50-60\% of most daily eider passes. Woodby and Divoky (1982), on the other hand, noted that males preceded female king eiders past Point Barrow during early spring migration in 1976 . Another similarity to the Point Barrow migration was the lack of immature eiders.

Eider flight through the study area did not appear to be influenced by fog or by time of day. The latter might not be the case early in king eider spring migration, as Woodby and Divoky (1982) found a pronounced peak movement of king eiders between noon and 1800 at Point Barrow, Alaska. Strong headwinds of over $50 \mathrm{~km} / \mathrm{h}$ appeared to hinder king eider migration at Holman Island. Other authorities have found the same effect of headwinds on eider migration (Johnson, 1971; Timson, 1976; Woodby and Divoky, 1982; Suydam et al., 2000b), although they defined adverse headwinds as blowing at more than $15 \mathrm{~km} / \mathrm{h}$.

\section{Harvest Rate}

Eiders migrating past Holman Island were more numerous in the open-water spring of 1998 than in the two preceding years. This does not support the suggestion of Fabijan et al. (1997) that fewer eiders are harvested in years of early open water because the eiders choose alternative routes, and fewer fly past Holman Island. Rather, our study showed that fewer eiders are harvested in years of early open water because there are fewer hunters. There is less participation in the hunt, likely because the open water renders eider-hunting areas inaccessible by snowmobile (more younger hunters own these than own boats) and the stable hunting platform of landfast ice is largely unavailable. In 1998, having to shoot either from a boat or from shore at ducks flying over open water increased crippling losses over the previous two years.

Harvest rates in 1996-98 were considerably lower than the rate that Smith (1973) observed in 1971 at Masoyuk. He estimated 5.2 eiders/man-hour for 11 hunters, which for an average eight-hour day is about 40 eiders per day for each hunter. By contrast, individual bags at Masoyuk in 1996-98 were never seen to contain more than 22 eiders per hunter, averaging between 7 and 10 in all years.

\section{Crippling Loss}

Smith's (1973) conjecture that eider crippling losses at Masoyuk are "probably high" is counter to our findings. Our results also show that recommendations that a $25 \%$ crippling loss rate be factored into Holman's annual eider harvest numbers (Fabijan et al., 1997) may not be appropriate in some years. The overall crippling losses around Holman Island were below 4\% in 1996 and 1997 and reached $20 \%$ only in 1998 , the year of early breakup.

The 3-20\% crippling loss rate observed at Holman Island for the "pass-shooting" hunt (i.e., shooting passing waterfowl without the aid of decoys) is lower than rates observed in some places in Alaska and southern Canada. 
Crippling loss rates of eiders were $30 \%$ to $40 \%$ at Point Barrow (Thompson and Person, 1963; Johnson, 1971), and more than $30 \%$ for spectacled eiders (Somateria fischeri) near St. Lawrence Island, Alaska (C.P. Dau, as reported by Fabijan et al., 1997). Prairie ducks had crippling losses of approximately $40 \%$ for a "pass-shooting" hunt (Nieman et al., 1987) and 36\% in decoy-hunting (Sowls, 1955; Hochbaum and Walters, 1984). In eastern Canada, Boyd (1971) estimated a cumulative crippling loss of $25 \%$ for 12 duck species. In Holman's hunting area, the lack of above-water obstacles into which downed ducks can be lost, such as high sea ice pressure ridges or emergent marsh vegetation, likely contributes greatly to limiting the losses there.

Contemporary Holman hunters use 12-gauge shotguns, with shells of $13 \mathrm{oz}$. loads of \#4 lead shot. It is unknown whether the coming transition to steel shot will alter the rate of crippling loss at Holman. Reviews of waterfowl crippling loss studies across the United States (Sanderson and Bellrose, 1986; Scheuhammer and Norris, 1995) concluded that the use of steel shot does not increase crippling losses, especially when hunters are trained in the modification of shooting technique that is necessary when using steel shot.

\section{Impact of Harvest on Eider Subpopulations}

Holman's harvests, with crippling losses factored in, removed between $3.5 \%$ and $7 \%$ of the king eiders and less than $1 \%$ of the common eiders that migrated past Holman Island in 1996-98. These estimates are likely maximums, because they are based on minimum estimates of the abundance of migrating eiders. Missing from our abundance estimates was an unknown (but probably minor) number of eiders that migrated farther offshore, out of sight of the shore-based observers (Byers, 1999). Conversely, our harvest estimates do not include the additional harvest from these same subpopulations that may occur when they are off Alaska and Russia. The harvest at Holman is only about $20 \%$ of the combined total harvest in western Arctic Canada and Alaska (Fabijan et al., 1997). Thus, the harvest in Alaska and Russia could be exerting additional pressure on Holman's eiders.

Recall surveys such as the IHS are often subject to bias (Usher and Wenzel, 1987; Biemer et al., 1991; Fabijan et al., 1997). However, the IHS's Holman eider recall survey was supplemented with checks of individual hunter bags from the community freezer by the IHS worker in Holman (D. Kuptana, pers. comm. 1997) This provided a crosscheck of the information received from hunters to help verify their accuracy. Also, $95-100 \%$ of the eider hunters at Holman participated in the harvest survey, which provided each hunter with a harvest calendar to record his daily take throughout the harvest period. Fabijan et al. (1997) determined that one potential source of bias, underestimating the total hunting population, was probably not a factor in the IHS eider harvest estimation. However, they maintained that there may be some underestimation of the total harvest since a small hunter population is harvesting a large number of eiders. If the IHS underestimated the eider harvest, then our estimate of the percentage of eiders that is harvested by the community of Holman is low as well.

It is unknown whether the harvest of eiders at Holman is sustainable. Sea ducks such as the king and common eider are long-lived compared to other waterfowl and have small clutch sizes and delayed sexual maturity (Palmer, 1976). Thus, a key factor influencing the stability of sea duck populations is adult survival, which makes them more sensitive to harvest than most other waterfowl species (Goudie et al., 1994). If we apply to eiders the maximum sustainable harvest level of $3-5 \%$ predicted for another long-lived sea duck, the harlequin duck (Histrionicus histrionicus) (Goudie et al., 1994), Holman's hunt was within sustainable limits for common eiders ( $<1 \%$ harvest of population), but perhaps not for king eiders (3.7-6.9\% harvest, including crippling losses). A population of common eiders in Denmark, however, increased over three decades despite an annual harvest of 5 $6 \%$ of the adults (Noer et al., 1995). The latter study suggests that the Holman harvest of king eiders is sustainable. However, without good estimates of natural mortality and productivity for king and common eiders, it is difficult to ascertain what harvest levels eider populations in the ISR can sustain. Given our current low level of knowledge of king eider population dynamics, periodic monitoring of a portion of the breeding population would probably be the most effective way to assess the sustainability of the eider harvest.

Overharvesting is unlikely to be the sole cause of the declines in the king and common eider populations that have occurred since 1976. Fabijan et al. (1997) noted that the harvest rate at the beginning of the declines was much less than the rate of declines. In addition, harvest pressure in Alaska and western Arctic Canada has been higher for king eiders $(2.5-5.5 \%)$ than for common eiders (1.6$3.5 \%$, yet both populations have declined at a similar annual rate since 1976 (3.9\% for king eider, and 3.6\% for common eider) (Fabijan et al., 1997; Suydam et al., 2000a). This suggests that another unknown factor or factors must be affecting the survival or productivity (or both) of at least the common eider.

\section{Cultural Factors Influencing Eider Harvest}

Advances in hunting technology probably brought about an increased eider harvest in the early part of the 20th century. Before firearms were introduced to Victoria Island in the 1910s, the hunting tools used to bag waterfowl were bolas, bows and arrows, and stone enclosures in which to entrap moulting birds (Farquharson, 1976). Condon (1996) quotes William Kuptana, at the time the oldest Copper Inuk in the ISR, as saying that three ducks bagged by bow and arrow was considered a very successful hunt. 
Eider harvests may not have continued to increase through the last half of the 20th century. Bromley's (1996) assertion that waterfowl harvests in the ISR have been increasing over the last three decades may not hold true for eiders, if we assume Smith's (1973) rough estimate of over 6000 eiders harvested at Masoyuk in 1971 was representative of harvest numbers throughout the 1970s. That number is double the mean annual harvest (about 3200) reported by the IHS over 10 years (1988-97) for the entire community, and is substantially greater than the largest estimated harvest during that period of approximately 4900 in 1988 (Fabijan et al., 1997; IHS unpubl. data). Although it can be argued that small sample size may have biased Smith's estimate upward (only 2 days were observed out of a hunt period of about 14 days), his estimate did not include what he considered to be sizeable portions of the harvest, namely (a) the take by child hunters, which he observed to be "considerable"; (b) the take by 14 other families presumed to have participated in the eider hunt; and (c) crippling losses. In addition, prominent Holman eider hunters reported to us that more ducks were taken in the 1960s and 1970s than in recent years (D. Kuptana, G. Okheena, pers. comm. 1998).

Though the human population of the Holman area increased steadily over 35 years, from 135 people in 1963 to 450 in 1997 (Abrahamson, 1964; Usher, 1965; Collings et al., 1998), it does not automatically follow that the waterfowl harvest should have increased commensurately. Berkes (1982) showed that although the James Bay Cree population of Kangiqsualujjuaq (Fort George), Quebec, had grown by $31 \%$ over eight years, their harvest of Canada geese had not increased at all, even though goose hunting remained a popular subsistence activity.

In Holman, socioeconomic factors mitigating the potential impact on eider stocks of an increasing human population include (a) replacement of a predominantly subsistence economy by an increasingly dominant wage economy, supplemented by social assistance, and (b) dietary change as a growing selection of southern-produced foods became available and affordable (Condon, 1983; Condon et al., 1995; Collings et al., 1998). In 1959, wild fish and game comprised $75-90 \%$ of the diet of Copper Inuit (Davies and Hansen, 1965). By 1993, almost two generations later, this had declined to $50 \%$ in Holman (Condon et al., 1995).

\section{Contemporary Importance of the Eider Hunt}

Holman accounts for nearly all of the eider harvest in the ISR (Fabijan et al., 1997). The relative availability of different waterfowl species in different parts of the ISR is undoubtedly responsible, at least in part, for geographic variation in harvest of a species (Bromley, 1996; Fabijan et al., 1997). The other ISR communities have access to large numbers of geese that fly past on migration, or that stage or breed on lands close by, but geese are not plentiful near Holman.

Eider hunting is a family event for many Holman Inuvialuit, and all family members can participate. We observed that even young children were involved, retrieving downed and crippled ducks. Individual hunting efforts were highly variable, depending on commitments to wage employment or differences in wild meat requirements. Greater requirements are attributable to having larger or extended families to feed, or greater culinary preference for this type of meat, or both.

Although waterfowl hunting continues to provide a nutritious source of fresh meat to many Holman families, it is no longer considered among the necessary elements of survival, as it was only 30 to 40 years ago. Nevertheless, the eider hunt appears to serve an important sociological function by maintaining a link to part of Holman's cultural and natural heritage and by strengthening kinship bonds.

\section{ACKNOWLEDGEMENTS}

We would like to thank the field crews who worked with dedication (and in all kinds of weather!) to obtain the migration and hunt monitoring data: Christine Brodie, Rod Brook, Wade Goin, Jennifer Joy, David and Joseph Kuptana, George Okheena, Chantal Pattenden, Hans and Kendra Schinke, and Michelle Tanguay. Thanks also go to the Holman Hunters \& Trappers Committee for their assistance and keen interest in this project. We also thank the Inuvialuit Game Council for allowing us to use the IHS data. Funding was provided by the Inuvialuit Final Agreement Implementation Funds and the Canadian Wildlife Service.

\section{REFERENCES}

ABRAHAMSON, G., ed. 1964. The Copper Eskimos: An area economic survey, 1963. Area Economic Surveys Report (AESR) 63:1. Ottawa: Department of Northern Affairs and National Resources.

ALEXANDER, S.A., DICKSON. D.L., and WESTOVER, S. 1997. Spring migration of eiders and other waterbirds in offshore areas of the western Arctic. In: Dickson, D.L., ed. King and Pacific eiders of the Western Canadian Arctic. Canadian Wildlife Service Occasional Paper No. 94. 6-20.

ANONYMOUS. 1968. Pilot of Arctic Canada. Vol. 3. Ottawa: Canadian Hydrographic Service, Department of Energy, Mines and Resources. 398 p.

BARRY, T.W. 1968. Observations on natural mortality and Native use of eider ducks along the Beaufort Sea coast. Canadian FieldNaturalist. 82:140-144.

1986. Eiders of the western Canadian Arctic. In: Reed, A., ed. Eider ducks in Canada. Canadian Wildlife Service Report Series No. 47. 74-80.

BERKES, F. 1982. Waterfowl management and northern Native peoples with reference to Cree hunters of James Bay. Muskox 30:23-35.

BIEMER, P., GROVES, R., LYBERG, L., MATHIOWETZ, N., and SUDMAN, S. 1991. Measurement errors in surveys. New York: John Wiley. 
BOYD, H. 1971. Observations on duck hunting in eastern Canada in 1968 and 1969. Canadian Wildlife Service Occasional Paper No. 12.22 p.

BRAHAM, H.W. 1982. Coastal migrating whales. In: Davis, D.E., ed. CRC handbook of census methods for terrestrial vertebrates. Boca Raton, Florida: CRC Press. 397 p.

BROMLEY, R. 1996. Characteristics and management implications of the spring waterfowl hunt in the western Canadian Arctic, Northwest Territories. Arctic 49(1):70-85.

BYERS, T. 1999. Eider spring migration past Holman, N.W.T. in 1996 to 1998. Unpubl. report by Byers Environmental Studies for the Canadian Wildlife Service, Environment Canada, Rm. 200, 4999-98 Avenue, Edmonton, Alberta T6B 2X3, Canada. $88 \mathrm{p}$.

COLLINGS, P., WENZEL, G., and CONDON, R.G. 1998. Modern food sharing networks and community integration in the central Canadian Arctic. Arctic 51(4):301-314.

CONDON, R.G. 1983. Inuit behaviour and seasonal change in the Canadian Arctic. UMI Research Press. Studies in Cultural Anthropology No. 2. 228 p.

- 1987. Inuit youth: Growth and change in the Canadian Arctic. New Brunswick: Rutgers University Press.

. 1996. The northern Copper Eskimo: A history. Norman, Oklahoma: University of Oklahoma Press.

CONDON, R.G., COLLINGS, P., and WENZEL, G. 1995. The best part of life: Subsistence hunting, ethnicity, and economic adaptation among young adult Inuit males. Arctic 48(1):31-46.

DAVIES, L.E.C., and HANSEN, S. 1965. The Eskimos of the Northwest Passage: A survey of dietary composition and various blood and metabolic measurements. Journal of the Canadian Medical Association 92(5):205-216.

DICKSON, D.L., COTTER, R.C., HINES, J.E., and KAY, M.F. 1997. Distribution and abundance of king eiders in the western Canadian Arctic. In: Dickson, D.L., ed. King and Pacific eiders of the Western Canadian Arctic. Canadian Wildlife Service Occasional Paper No. 94. 29-39.

FABIJAN, M., BROOK, R., KUPTANA, D., and HINES, J.E. 1997. The subsistence harvest of king and Pacific eiders in the Inuvialuit Settlement Region, 1988-1984. In: Dickson, D.L., ed. King and Pacific eiders of the Western Canadian Arctic. Canadian Wildlife Service Occasional Paper No. 94. 67-73.

FARQUHARSON, D. 1976. Inuit land use in the west-central Canadian Arctic. In: Freeman, M., ed. Inuit land use and occupancy project. Vol. 1. Ottawa: Supply and Services Canada. $33-62$.

FOURNIER, M.A., and HINES, J.E. 1994. Effects of starvation on muscle and organ mass of king eiders Somateria spectabilis and the ecological and management implications. Wildfowl 45: $188-197$.

GOUDIE, R.I., BRAULT, S., CONANT, B., KONDRATYEV, A.V., PETERSEN, M., and VERMEER, K. 1994. The status of sea ducks in the North Pacific Rim: Toward their conservation and management. Transactions of the North American Wildlife and Natural Resources Conference 59:27-49.

HOCHBAUM, G.S., and WALTERS, C.J. 1984. Components of hunting mortality. Canadian Wildlife Service Occasional Paper No. 52.28 p.
JOHNSON, L.L. 1971. The migration, harvest and importance of waterfowl at Barrow, Alaska. M.S. Thesis, University of Alaska, Fairbanks. 87 p.

KAY, D., KORNDER, M., and HINES, J. 1996. Inuvialuit traditional knowledge of king eider (Somateria spectabilis), Pacific eider (Somateria mollissima v-nigra), and black brant (Branta bernicla) at Holman and Sachs Harbour, N.W.T. Unpubl. report available at Environment Canada, P.O. Box 2970, 5204 50th Ave., Yellowknife, Northwest Territories X1A 2R2.

NIEMAN, D.J., HOCHBAUM, G.S., CASWELL, F.D., and TURNER, B.C. 1987. Monitoring hunter performance in Prairie Canada. Transactions of the North American Wildlife and Natural Resources Conference 52:233-245.

NOER, H., CLAUSAGER, I., and ASFERG, T. 1995. The bag of eider Somateria mollissima in Denmark. Danish Review of Game Biology 14(5):3-24.

PALMER, R.S., ed. 1976. Handbook of North American birds. Waterfowl, Part 2, Vol. 3. New Haven, Connecticut: Yale University Press. 560 p.

RUGH, D.J., and BRAHAM, H.W. 1979. California gray whale (Eschrichtius robustus) fall migration through Unimak Pass, Alaska, 1977: A preliminary report. Report of the International Whaling Commission 29.

SANDERSON, G.C., and BELLROSE, F.C. 1986. A review of the problem of lead poisoning in waterfowl. Illinois Natural History Survey. Special Publication No. 4. 34 p.

SCHEUHAMMER, A.M., and NORRIS, S.L. 1995. A review of the environmental impacts of lead shotshell ammunition and lead fishing weights in Canada. Canadian Wildlife Service Occasional Paper No. 88.

SMITH, M., and RIGBY, B. 1981. Distribution of polynyas in the Canadian Arctic. In: Stirling, I., and Cleator, H., eds. Polynyas in the Canadian Arctic. Canadian Wildlife Service Occasional Paper No. 45. 7-28.

SMITH, T.G. 1973. The birds of the Holman region, western Victoria Island. Canadian Field-Naturalist 87:35-42.

SOWLS, L.K. 1955. Prairie ducks. Harrisburg, Pennsylvania: Stackpole. $193 \mathrm{p}$.

SUYDAM, R., QUACKENBUSH, L., JOHNSON, M., GEORGE, J.C., and YOUNG, J. 1997. Migration of king and Pacific eiders past Point Barrow, Alaska, in spring 1987, spring 1994 and fall 1994. In: Dickson, D.L., ed. King and Pacific eiders of the Western Canadian Arctic. Canadian Wildlife Service Occasional Paper No. 94. 21-28.

SUYDAM, R.S., DICKSON, D.L., FADELY, J.B., and QUAKENBUSH, L.T. 2000a. Population declines of king and common eiders of the Beaufort Sea. Condor 102:219-222.

SUYDAM, R.S., QUAKENBUSH, L.T., DICKSON, D.L., and OBRITSCHKEWITSCH, T. 2000b. The migration of king (Somateria spectabilis) and common (S. mollissima v-nigra) eiders past Point Barrow, Alaska during spring and summer/ fall 1996. Canadian Field-Naturalist 114(3):444-452.

THOMPSON, D.Q., and PERSON, R.A. 1963. The eider pass at Point Barrow, Alaska. Journal of Wildlife Management 27: $348-356$

TIMSON, R.S. 1976. Late summer migration at Barrow, Alaska. In: Environmental assessment of the Alaskan Continental Shelf 
Principal Investigator's Report, April-June 1976. Vol. 1. Boulder, Colorado: National Oceanographic and Atmospheric Administration. 354-400.

USHER, P. 1965. Economic basis and resource use of the Coppermine-Holman region, N.W.T. (NCRC-65-2) Ottawa:

Department of Northern Affairs and Natural Resources. 290 p.
USHER, P., and WENZEL, G. 1987. Native harvest surveys and statistics: A critique of their construction and use. Arctic 40(2): $145-160$.

WOODBY, D.A., and DIVOKY, G.J. 1982. Spring migration of eiders and other waterbirds at Point Barrow, Alaska. Arctic 35(3):403 - 410. 